(C) 2021 American Psychological Association

https://doi.org/10.1037/scp0000282

This article may not exactly replicate the authoritative document published in the APA journal. It is not the copy of record. 


\title{
The Clinical Scope of Islamic Psychotherapy: A Grounded Theory Study
}

\author{
Abdallah Rothman ${ }^{1}$ and Adrian Coyle ${ }^{2}$ \\ ${ }^{1}$ Cambridge Muslim College, Cambridge, United Kingdom \\ ${ }^{2}$ Kingston University London, United Kingdom \\ Corresponding author: Dr Abdallah Rothman, Principal, Cambridge Muslim College, 14 St Paul's \\ Road, Cambridge CB1 2EZ, United Kingdom. Email: aer@cambridgemuslimcollege.ac.uk
}

Dr Abdallah Rothman is the founder of Shifaa Integrative Counseling, co-founder and Executive Director of the International Association of Islamic Psychology, and the Principal of Cambridge Muslim College in the UK. He is a Licensed Professional Counselor (LPC) and a Board Certified Registered Art Therapist (ATR-BC), working at the intersection of Islamic spirituality and mental health practice. Dr Rothman holds an MA and PhD in Psychology. His clinical practice and his academic research focus on approaching psychotherapy from within an Islamic paradigm and establishing an indigenous Islamic theoretical orientation to human psychology that is grounded in the knowledge of the soul from the Islamic tradition. He was a student of the late Professor Malik Badri and, in addition to his academic training, he has studied privately with a number of traditional Islamic scholars throughout the Muslim world.

(C) 2021, American Psychological Association. This paper is not the copy of record and may not exactly replicate the final, authoritative version of the article. Please do not copy or cite without authors' permission. The final article will be available, upon publication, via its DOI: $10.1037 /$ scp0000282 


\title{
The Clinical Scope of Islamic Psychotherapy: A Grounded Theory Study
}

\begin{abstract}
This paper presents findings from a study which examined the application of an Islamic model of the soul in psychotherapy. It addresses the clinical scope of an Islamic psychotherapy. Interviews with 18 psychotherapists who believed they integrate Islamic conceptions of psychology into their practice were analysed using a grounded theory approach. Findings centered on the stages of the soul with which Islamic psychotherapy is concerned and the potential for inter-stage movement, and the relationships between and demarcation of the roles of Islamic psychotherapist and religious guide or shaykh. A data-grounded model of the clinical scope of Islamic psychotherapy is presented.
\end{abstract}

\section{Keywords}

Islamic psychology, Islamic psychotherapy, spiritual care, spiritually integrated psychotherapy 


\section{Introduction}

The development of research-based indigenous approaches to Islamic psychotherapy has only recently begun to gain concerted momentum. What we term 'indigenous approaches' are those grounded in an Islamic psychology that is rooted in a model of the person derived from Islamic theology, philosophy, ethics, and guidance (Rothman, 2021). Such approaches aim for an Islamic integrity that is lacking in Islamized versions of Western secular psychotherapies where core concepts are modified to try to accommodate Islamic values and commitments. However, attempts to develop and evaluate psychotherapeutic interventions based on Islamic versions of psychology have often been limited in terms of the nature, grounding or breadth of the underpinning Islamic framework or the reported interventions (for example, Abdullab, 2007; Abdullah et al., 2013; Al-Karam, 2018; Keshavarzi and Haque, 2013; Naz and Khalily, 2015).

Given the lack of development of and therefore research into indigenous approaches to Islamic psychotherapy, it has been unclear what the scope of such therapy might be. It might be assumed that a religious orientation to psychotherapy is focused primarily on the spiritual beliefs of clients and that the range of what such approaches can address is limited to aligning with religious teachings rather than addressing serious mental health issues. The question can also arise as to just how far religiously-oriented psychotherapy can or should delve into matters of spiritual development and where the line should be drawn in terms of addressing one's psychological state for the purpose of mental health versus spiritual guidance. This purpose of the study presented here addresses the need to define the clinical scope of Islamic psychotherapy in an attempt both to construct appropriate parameters for professional capacity and to distinguish it from traditional religious guidance within the context of the Islamic tradition.

As has been the case with the development of Christian psychotherapy, practitioners have recognized the importance and utility of the mental health field in offering a fitting venue for carrying on the Christian tradition of 'soul care' (Hathaway, 2009). Richards (2010) illuminates the fact that while the perception of psychotherapy as a science removed from the realm of religion may be 
prominent, the field has always had integral ties to religious thought and tradition. While the term 'pastoral counseling' now refers to a much broader concept not necessarily connected with any particular religion or spiritual tradition, it has long been an integral part of the Christian tradition (Evans, 2000). Christian mental health practitioners have been able to use that as a precedent for further developing a model of Christian counseling that utilizes the familiar language and concepts of psychotherapy (Hathaway, 2009). The Association of Pastoral Counselors in America defines pastoral counseling as "a process in which a pastoral counselor utilizes insights and principles derived from the disciplines of theology and the behavioral sciences in working with individuals, couples, families, groups, and social systems towards the achievement of wholeness and health" (Strunk, 1993, p.15). The closest thing to this in the Islamic tradition is that of the role of a shaykh for Muslims to receive personal religiously-oriented developmental and spiritual guidance; however, that is now mostly confined to Sufism (Jurich, 1998). Thus, the most common outlet that Muslims have for receiving religiously-oriented counsel is from Imams (Muslim religious leaders) in local Muslim communities, many of whom are not equipped for such responsibility and do not have an overt understanding of how to integrate Islamic teachings with personal 'pastoral counseling' (Ali, Milstein \& Marzuk, 2005).

Although there have been efforts toward this aim, more research is needed in this area to support the further development of informed approaches to incorporating Islam into psychotherapy. We have sought to address this firstly by presenting an Islamic model of the person or 'soul', crafted from an analysis of interviews with scholars and practitioners in Islamic psychology, philosophy, religion and spirituality (Rothman \& Coyle, 2018). That model focused on participants' understanding of the nature, structure, stages and development of the soul within the Islamic tradition and drew upon their familiarity with original sources within Islamic philosophy and ontology. We then built upon this to develop a data-grounded, experience-based model of Islamic psychotherapy through the analysis of interviews with Muslim psychotherapists who believed that they integrate Islamic conceptions of psychology into their clinical practice (Rothman \& Coyle, 2020). One important question that remains to be addressed concerns the scope of an Islamic psychotherapy. Specific issues that need to be 
clarified relate to its role in facilitating spiritual development for Muslim clients (and hence the nature and limits of the role of the Islamic psychotherapist) and its capacity to engage with mental health issues (or reconfigured understandings of these) in constructive, systematic ways. This clarification of the clinical scope of Islamic psychotherapy is necessary for identifying appropriate parameters for the endeavour and its practitioners and for distinguishing it from religious guidance practices within the Islamic tradition. The present paper engages with this task in a data-grounded way.

What is evident is that any psychotherapy that aims to be truly Islamic and take the Islamic understanding of the person as its foundations will be located outside Western secular models of psychotherapy in fundamental ways. This means that some basic questions, such as its clinical scope, need to be examined afresh rather than assuming that conclusions about and standard practices within secular psychotherapies can be applied to an Islamic psychotherapy. In its examination of the clinical scope of Islamic psychotherapy, this paper extends the analysis presented in Rothman \& Coyle (2020) where we developed a data-grounded theory of Islamic psychotherapy. There we elaborated the ways in which Muslim psychotherapists applied the four levels of the "Structure of the soul" (nafs, 'aql, $q a l b$, and $r u \bar{h}$ ) in conceptualizing an Islamic psychotherapy. That category, together with the category concerning the "Nature of the soul", constituted what participants believed to be the foundations of how psychotherapy should be understood within an Islamic paradigm. In the present paper, that theory is extended to engage with questions of clinical scope, by focusing on the remaining two categories of "Stages of the Soul": the potential for human growth and development, and "Development of the Soul": the process of actualizing that potential. The same set of qualitative interviews with the same Muslim psychotherapists is used here, although different parts of those interviews are focused upon. 


\section{Method}

\section{Participants}

Eighteen psychotherapists were recruited who believed that they integrate Islamic conceptions of psychology into their clinical practice and who could therefore act as "key informants" concerning the integration of Islamic principles in therapeutic approaches. Most were identified prior to the commencement of data generation by the first author, but others were identified through recommendations and "snowballing". All had trained in a form of Western secular therapeutic practice and some had training specific to an Islamic approach. The group of participants consisted of 12 men and six women coming from six countries across four continents ranging in age from 26 to 89 years. Participants were categorized into three different types of integration on the basis of their accounts of applying and integrating Islamic principles. Participants' designated pseudonyms, the country where they practise, their therapeutic training, and their type of integration can be found in Table 1.

[Insert Table 1 about here]

Six of the participants aimed to integrate Islamic principles into their practice of Western secular therapy with Muslim clients in an ad hoc way, engaging within their practice the first two or three levels of the soul (indicated in the top right of Table 1). These participants' augmented their Western training with their own independent study of Islamic theology. Eight participants had some form of Islamic religious training and integrated that knowledge into their psychotherapy practice, engaging the first three or four levels of the soul (indicated in the middle of the right-hand column in Table 1). These participants did not actively incorporate inner spiritual reflection, or tazkiyat an nafs ("purification of the soul"), into their clinical practice. Four participants practised from a uniquely Islamic perspective within a framework of traditional Islamic spirituality, engaging all four levels of the soul. Those in this group (indicated at the bottom of the right-hand column in Table 1) had traditional training in tazkiyat an nafs with a Sufi shaykh and worked from within an Islamic spiritual framework. 


\section{Data generation}

The generation of data was through individual, semi-structured interviews conducted by the first author. The interviews were made up of open-ended questions that were designed to help participants share their personal experiences of their therapeutic practice and how they integrate Islamic principles. First, participants were asked to describe their approach to working with clients in a way that is informed by Islamic principles. Next, the interview focused on categories and concepts from the Islamic model of the soul described by Rothman \& Coyle (2018). That model was shown to participants later in the interview, after expressing their own views, and were asked how they might apply aspects of it in their own clinical practice.

When a favourable ethical opinion on the research had been received from the authors' university, the interview schedule was piloted with two Muslim clinicians, resulting in minor changes. Eight interviews were then conducted in person and 10 by video conference over the course of the study. Interviews on average lasted 60 minutes and each was digitally recorded and then transcribed verbatim.

\section{Data analysis}

As in the other parts of this project (Rothman \& Coyle, 2018, 2020), a grounded theory approach was adopted (Glaser and Strauss, 1967). This enables new theoretical insights to be developed from a systematic analysis of qualitative data and is particularly useful in areas where existing theory is incomplete, inappropriate or entirely absent. Specifically, we used the version of grounded theory formulated by Charmaz (2014) which builds upon the original version described by Glaser and Strauss (1967). By examining clinical scope and extending the model of Islamic psychotherapy that we presented in Rothman \& Coyle (2020), this paper exemplifies an important stage in any ongoing grounded theory process whereby a theory or model that has been developed in one study is tested and/or elaborated in subsequent studies with related foci. 
In grounded theory work, a new theory is inductively crafted through a recurrent sequence of data generation and data analysis and a distinctive approach to sampling. After an initial sample has been recruited and data have been generated, those data are subjected to systematic analysis. The researchers assign labels or "codes" to units of meaning within the data (that is, words, phrases, sentences or larger segments of text relevant to the research focus) in a process known as "open coding". These codes seek to capture the core features of the units of meaning. Normally, through the constant comparison of codes and the identification of connections between them, researchers develop higher-level "theoretical categories" that organize the data. However, in this study, theoretical categories were imported from the previous phase of the study and the open coding process was focused on identifying how those categories function or change when applied in the context of psychotherapy.

The application of the theoretical categories was refined and developed through a process known as "axial coding". Within the process of axial coding, potential relationships between these categories were noted, hypotheses were formed and then tested by returning to the field to seek participants who might be able to add new perspectives to the data set enabling the categories to be elaborated, confirmed or queried. This ongoing sampling process is driven by the categories that, in their finalized form, ultimately constitute the resources from which new theory is crafted. Hence it is termed "theoretical sampling". In the present study, for example, theoretical sampling was used when it became clear that most of the participants who were interviewed in the early stages of fieldwork were using the mode of integration in the top right of Table 1. Practitioners who used a more specific and deliberate Islamic approach were then sought. To take another example, when a participant who was trained in Islamic spiritual healing provided insights that extended the emergent categories in new ways, other practitioners who had that experience were sought and were invited to participate.

The iterative fieldwork-analysis process ideally occurs until "saturation" is reached, that is, until no new examples relevant to the categories are identified through fieldwork and a theory can be developed from the categories that can explain all variations in the data (Payne, 2021). 
In the present study, saturation was held to have occurred just before the eighteenth participant's transcript was analysed because data collected from interviews at this point were only producing recurring codes. (As we note in the discussion section, however, in retrospect we might usefully have extended our theoretical sampling.) The emergent understanding of the scope of Islamic psychotherapy was then re-grounded by going back to the data and validating it against interview text (Payne, 2021).

\section{Quality control}

This study was guided by the criteria for excellence in qualitative work identified by Tracy (2010) to ensure quality. These included the worthiness of the topic, resonance, the significant contribution of the work, and rich rigor. For the sake of transparency, it is worth noting the researchers' 'speaking positions.' Both researchers share a longstanding interest in the relationship between religion and psychotherapy, including the potential benefits and challenges of integrating religion into psychotherapy. For the first author, this interest has been explored largely within an independent practice setting, integrating Islamic principles into psychotherapy with Muslim clients. For the second author, this interest has been explored mainly through conducting a body of relevant qualitative research over some years, informed by concepts from psychotherapeutic and social psychology. Both authors have longstanding religious commitments: the first author is a practising Muslim, having converted to Islam in 2005, and the second author's religious position is principally informed by Jewish and Christian sources. These sometimes different and sometimes complementary standpoints enabled the development of an analysis that was scrutinized from useful vantage points and that was not idiosyncratic. Findings were shared with various stakeholder audiences which provided external scrutiny and evidence of resonance. 
In the data excerpts that are used to illustrate the clinical scope of Islamic psychotherapy in the next section, pseudonyms have been assigned to participants; dots indicate pauses in participants' speech; and clarificatory material appears within square brackets.

\section{Results}

As we noted earlier, in Rothman \& Coyle (2020), we addressed how participants applied the category of the "Structure of the soul" in conceptualizing an Islamic psychotherapy because that category, together with the "Nature of the soul", constituted what participants believed to be the foundations of how psychotherapy should be understood within an Islamic paradigm. In the present paper, the resultant model of Islamic psychotherapy is extended by focusing on the two remaining categories: "Stages of the soul" and "Development of the soul", as participants believed these to be relevant to praxis in that they constitute mechanisms for change. These represent a further exploration of foundational principles and their application in practice with specific reference to the clinical scope of Islamic psychotherapy. This discussion of scope centers on the stages of the soul with which Islamic psychotherapy is principally concerned and the potential for movement between stages, and the relationships between and demarcation of the roles of Islamic psychotherapist and religious guide or shaykh. Table 2 presents these categories and the new insights related to them based on the participants' input from this study (seen in the sub-categories) which help to develop the model in light of their clinical experience. These will be selectively elaborated with the focus on material that is important to the clinical scope of Islamic psychotherapy. (The sub-category of "Development of the soul of the client" will not be addressed due to space constraints and because its contents overlap with the material under "Stages of the soul". See also Rothman \& Coyle, 2020, for more on this issue.)

[Insert Table 2 about here] 


\section{Stages of the soul}

Participants agreed that most of their psychotherapeutic work, at least initially or with short-term clients, is focused at the level of nafs (lower self) because that is where most of the visible manifestation of psychological and/or spiritual imbalance appears. When it came to talking about the stages of the soul (nafs al-ammārah bil su or "soul that incites to evil", nafs al-lawwämah or "selfaccusing soul", and nafs al-mutma'innah or "soul at rest"), those participants who were familiar with Islamic teachings about them conceived of them as different manifestations of the same nafs, as qualities that the nafs takes on based on the person's degree of jihäd an nafs ("struggle of the soul"). Participants said that when a person is not exerting much effort in their jihād an nafs, then the nafs is in the stage or state of ammārah bil su, where the person is following base inclinations that pull them further away from fitrah (the innately pure and good nature of the human soul) and tend to result in psychological imbalance, dysfunction or ghafla (a state of forgetfulness or heedlessness of God). However, they reported that when the nafs is in a state of struggling to control itself, then it has the quality of lawwāmah, where it is attempting to regulate itself and find equilibrium. Participants emphasized that this change in the state of the nafs is very volatile and can fluctuate based on the client's will and self-control. As Maha said, "Every day we go out and we have the potential to come back home with nafs al-ammärah bil su or to come back home with the nafs al-muța innah... It's literally a daily thing and it's a fact that it's a moment-to-moment thing."

\section{Majority of psychotherapy is between Nafs Al-ammārah bil su and Nafs al-Lawwāmah}

Many participants voiced the opinion that movement between the stages of the soul is not only natural and healthy but that, in the therapeutic process, the therapist should seek to encourage movement in an ascending direction from nafs al-ammārah bil su to nafs al-lawwāmah to nafs al-muța 'innah.

Such movement was seen as the dynamic that activates and feeds the balancing process and so enables equilibrium and healing. 
This idea was developed further by some participants who said that if a person remains in either of the two lower stages for too long, this can become problematic. Specifically, they expressed the belief that if a person stays in nafs al-ammārah, they can become pathologically hedonistic or even narcissistic, feeding the ego and being overtaken by a constant preoccupation with fulfilling their every desire to enact selfish tendencies. In the accounts given by many of the participants, it was apparent that narcissism - a pathological preoccupation with aggrandizing the self - is considered a serious psychological disorder from an Islamic perspective. This comes from a central tenet in Islam that a Muslim is a servant of God and anything good that comes from him or herself is a blessing from God and not due to the person's own goodness. The state of rejecting this idea and adopting a belief that one is self-directed, not subject to the will of God and thus individually deserving of praise, is likened to the state of shaytān or iblis (Satan), whom several participants referenced as the ultimate narcissist. Participants explained that a healthy amount of narcissism is needed for self-preservation, self-love and self-motivation but that it needs to be tempered and brought into balance with selfregulation, which is the domain of nafs al-lawwämah. In this vein, Hamit said:

"Your impulses might be healthy. There are biological drives and there are healthy routes for that. But then there is unhealthy and that's where your nafs al-lawwämah comes in. It is not just a critic that's trying to get you to socially comply. It's for your own good.”

The idea expressed here and by the others who talked about this dynamic is that nafs al-lawwämah is a necessary stage that the soul must move into by exerting the will in the processes of jihäd an nafs and tahdhīb al-akhlāq ("reformation of character") in order to regulate those natural tendencies and keep them from becoming pathological or creating imbalance in the whole system. While the nafs allawwämah in an imbalanced state can become an overly critical voice within the person (as Hamit alluded to), with the right balance it was seen to be capable of acting as a regulating factor within the person's psyche. 
Similar to the idea of nafs al-ammārah bil su potentially becoming pathological if the person remains there, Enas discussed the dangers of staying in the stage of nafs al-lawwämah. In describing the effort that the person exerts in the jihäd an nafs and in striving toward the development of the munjiyat ("virtues"), she said:

"You use here al-lawwämah - the self-reproaching soul. You can make benefit of the selfreproaching soul. It is a device. Nafs al-lawwämah is a device. For this, I think the selfreproaching soul is very positive unless you are stuck here. If you settled in the reproaching soul, it is pathological and you will get a serious illness, like neurotic guilt, maybe psychotic. You may punish yourself."

These participants described the danger of staying in lawwāmah as being one where the natural function of this stage becomes unhealthy and detrimental, causing psychological imbalance and emotional blocks. Rayyan described it like this:

"The nafs al-lawwāmah that has been hijacked, which I see a lot, which is, you know, the low self-esteem and self-deprecation and always hating yourself and always thinking of yourself as wrong and 'I can't do anything right.' So I see that as, you know, nafs al-lawwāmah is healthy, and which you know when you've done something wrong, you reproach yourself. However, because of the culture in which most of my clients are coming from, which is built on guilt and shame, and often religion and family structures are built on fear and guilt, and then a lot of them come with this nafs al-lawwämah that comes with a lot of negative thoughts and oppressive thoughts to themselves. And so here we work on trying to get them to not remove the nafs al-lawwämah right then because they're going to fall into nafs alammārah, but to go past the nafs al-lawwāmah and into the nafs al-mutma'innah, where I can hear a thought and I will process it. I will say, 'OK if I'm wrong then what can I do to do better?"”

The cultural context that Rayyan refers to above is that of Arab Muslim and/or Muslim majority countries where Islamic religious teaching is embedded within and often confused with cultural assumptions and expectations. For example, while the Qur'an and Islamic teachings are 
replete with assertions that God is the All-Merciful and All-Forgiving, cultural norms and expectations within interpersonal relationships often generate longstanding patterns of shame, guilt, and a sense of not being "good enough". Many participants talked about how these ingrained patterns damage a person's relationship to the All-Merciful God and that much of their work as therapists in the initial stages of therapy is focused on reorienting clients' relationship with God and themselves and instilling a sense of love and mercy for self as a reflection of the love and mercy of God.

\section{Movement through the stages as treatment goal}

Extending the dynamic motif of the preceding sub-category, the participants in the bottom right corner of Table 1 (those who engaged actively with all four levels of the soul) provided much more material on how to engage clients in moving into nafs al-mutma'innah than other participants did. It was primarily only Harun, Enas and Mustafa who shared practical tools that they use within therapy to encourage movement towards or at least enable a taste of this stage of the soul. This was primarily done through the use of Islamic practices such as murāqabah and tafakkur. According to participants, murāqabah can be understood as watchfulness of the self, where a person brings their attention inward and enters into a state of presence with their inner self. Tafakkur was translated as 'contemplation' and described as a process of reflecting on the majesty of God's creation (for example, being in awe of the natural environment and its interconnectedness). This is meant to lead the person to a place of inner peace and calm within, ultimately focusing on God alone as the source of all creation. Mustafa described tafakkur in an Islamic context and how he uses guided imagery with clients:

"In Islam contemplation is appreciation first, that is to cross from the beauty of the things to its creator. Tafakkur I think it has its steps to me, there is the way, just get to appreciate creation. Then you move from the appreciation to the creator of this thing that you have appreciated because I think that people who are not Muslim, who don't believe in God, also appreciate the beauty of nature. Once you get to appreciate, then this will move you gradually to close your eyes, take a deep breath and imagine yourself in the ocean and you can hear the 
waves coming onto the shore, making this noise. You can see far away, you can hear children playing, you can hear them. Until he really imagines this very well, now if from this you go to the creator, Allah is overlooking all this."

Mustafa went on to explain that guiding a client to experience this serene state of interior calmness, while witnessing the power or glory of God, gives them a taste of what nafs almutma'innah feels like. They then know what they are striving for and can work toward returning to that place.

Enas described a similar practice of guided imagery that she uses with her clients. Here she recounts what one of her clients shared with her after experiencing this:

"They feel that there is a divine existence. When one of the patients said 'When you told me about that, I see the universe, I saw the stars and planets. I saw that I am big but because of Allah's support. Not big by myself, not high self-esteem, not ego - the rūh. I felt that Allah is protecting me. I felt that everything can harm me before is very small. And [I] was completely protected by light."”

Participants reported these types of guided experiences to be very useful and powerful in enabling clients to connect with God in ways beyond the narrowly rational, especially during difficult life circumstances or in the midst of psychological problems. However, it was understood by all participants that living in the stage of nafs al-mutma 'innah is very difficult and not practical, nor is it within the scope of psychotherapy treatment for most clients. Yet, according to the few participants who used them, these practices appeared to help clients at least to cross into this more advanced stage, with the expectation that they would vacillate back and forth. Mustafa explained that his aim in using tafakkur in therapy was to build on experiences that clients may already have glimpsed and to strengthen or extend those experiences as resources to draw upon in the future. He said:

"It is rare not to find a patient who has had such a feeling in his own place, the palm trees in the desert he sat down for a time, when were you most happy when you are watching nature, he will mention then I come to make him relive this again." 


\section{Nafs al-Mutma 'innah and beyond}

Although participants talked about the nafs al-mutma'innah as being crucial for motivating movement beyond nafs al-lawwämah, they agreed that it is unlikely that a person will be able to dwell there. The consensus was that, if a person were to be able to do that, they would have graduated beyond what Islamic psychotherapy can offer. Several participants said that they see their work lying within ammārah and lawwämah with the goal being to get the client to the door of mutma'innah. However, they mostly agreed that, beyond that point, it was appropriate for the therapist to refer the person to a shaykh (spiritual mentor) to guide them on a more explicitly religious path of spiritual development. Commenting on this, Rayyan said:

"So obviously for me to get them to be stationed in nafs al-muța' innah is hard because you would need someone very powerful for that, like a shaykh. But they get flashes of it, glimpses of it. And when they get those glimpses, it feels so natural, like 'Finally I'm functioning.' And when they feel that on their own, they are the ones who then strive and work hard to get themselves to the nafs al-mutma'innah. Then they will work on their own to get there or they'll seek a person outside of me who is more specialized in that to help them in that way."

When reflecting on the conceptualization of Islamic psychotherapy in relation to the nature and structure of the soul, participants had indicated the need to rely on Islamic scholars for issues pertaining to religious knowledge (Rothman \& Coyle, 2020). Here, though, what Rayyan is referring to is somewhat different. Whereas a religious scholar can offer knowledge from the memorization of texts and understanding of their meanings within Islamic thought and belief, a shaykh of tașawwuf (traditional Islamic spirituality commonly termed 'Sufism') was seen by most participants to be someone who, in addition to book knowledge, has experiential knowledge of the soul due to their own elevated spiritual state. Many participants said they perceive a point within their psychotherapeutic work beyond which the further development of the soul requires the input of a shaykh of tașawwuf. This will be elaborated when we examine the process of 'Defining and demarcating the role of the Islamic therapist'. This further development of the soul is based on the conception that there are 
higher states beyond nafs al-muța'innah (referenced in Islamic sources and mentioned by participants in Rothman \& Coyle's, 2018, study of the Islamic model of the soul). Enas referenced these additional stages of the soul, saying, “The Qur'an says, irj' ila Rabika radiyyatan mardiyyah. It is just an emotional status, something like this - 'Return to your lord well pleased and well pleasing.' Still there is more definition, more and more." Here she explains that these additional stages beyond nafs al-mutma 'innah (nafs al-radiyyah or 'soul well pleased' and nafs al-mardiyyah or 'soul well pleasing') are higher states of the soul as it progresses, although most people do not attain them.

\section{Development of the soul}

Development of the soul of the client: Treatment approach

Most participants expressed a shared understanding that the Islamic approach to psychotherapy aims to uncover the true self that exists in potentia, underneath psychological problems and imbalances, and to connect the client to this deeper level of their identity in relation to God and their primordial truth beyond this dunya (temporal, material world) existence where these presenting problems manifest themselves. Problems and psychological issues were seen not only as symptoms of a deeper issue but as signposts along the path of actualizing the true self - that is, in the fitrah state, the rūh aspect of the soul, the divine spark that is connected to God - that lies beneath the experience of the perceived self.

\section{Development of the soul of the therapist: Training approach}

All participants believed that to fulfil their role as Islamic psychotherapists and help clients with their soul development, they needed to work on their own soul development. They saw this as part of their life journey as Muslims but also as training for their therapeutic role. Being an Islamic psychotherapist was not seen as involving a detached practitioner applying a therapeutic model in a technical way. Rather it was seen as requiring a deeply personal investment and commitment from the Islamic psychotherapist. In this sense, participants' conceptualization of the role echoed 
understandings of the position of the secular psychotherapist, especially in the psychoanalytic and humanistic traditions. In those contexts, the practitioner is expected or required to undergo therapy themselves as part of their training and/or on an ongoing basis. While all participants had extensive training in various approaches to therapy, they accorded central importance to their own state of psycho-spiritual development in enabling them to undertake their role effectively.

\section{- Defining and demarcating the role of the Islamic therapist}

Given that an Islamic psychotherapist was seen as someone who integrated Islamic principles into psychotherapy, there was a pronounced awareness among participants that their role can come close to crossing into that of a religious guide. Many participants discussed the need to clarify and emphasize the distinction between a practitioner of psychology/psychotherapy and a religious guide both for clients and seemingly for themselves as well. Enas said, "I mean, you are not a religious guide. You are not a religious guide - you are a therapist. 'Therapist' means that you know the rules of the human being, the psychological laws. So, you apply or implement according to what you know about the human being." This was reflected in most participants' views that the primary goal of an Islamic psychotherapist is not to help clients become better Muslims or understand Islam better. Instead, they stressed that the goal of a practitioner of Islamic psychotherapy is the same as the goal of any psychotherapist: to help alleviate psychological distress and dysfunction and encourage healthy growth.

However, participants understood that there was a potential lack of clarity and a need for demarcation, given that, in their work with clients, they engage with spiritual matters with regard to the development of the soul. Moreover, Enas went on to say that, while she does not see herself as a guide to Islam, she does acknowledge that God plays a role in her work. Her understanding, which was shared by many participants, was that God is the one who helps a client to heal, so any positive breakthroughs or successes in therapy are attributed to God. These participants saw themselves as working in partnership with God in their therapeutic work. However, Enas noted that while she believes this, she does not bring this to the client's attention lest it undermine therapeutic processes. In 
relation to transference, she said, "The client thinks that you indeed have superpowers. I mean he must not understand that Allah helped you, for transference will not happen if you told him it's Allah." Her understanding of the process of therapeutic change is a dual one: change is seen as occurring through working with transference (a standard idea in psychodynamic work) but that process is seen as undergirded by divine action.

Similarly, Samir conceptualized his role as an Islamic psychotherapist as resonating with secular models of counseling. He pointed to the core emphasis on the therapeutic relationship within his approach to counseling. This can readily be seen as a feature of person-centered therapy but he also understood it in terms of his Islamic framework:

"I always try to ground my counseling and my counseling relationship that I use that as a cornerstone regardless of the theoretical underpinning of my work because I feel that if we establish the trust and the ability for the client to relate to me, I think that's, that's really important. From an Islamic perspective, in terms of how the Prophet salalahu alayhi wa salam [peace and blessings upon him] used to deal with people and make people, regardless of their background, the most important person. He would pay full attention, and subhan Allah [glory to God] research in modern times says that's really important - the relationship is the core for positive outcomes of counseling."

Like Samir, Shahid invoked the Prophet Muhammad in conceptualizing his role as an Islamic psychotherapist:

"When I meet a new client, I often describe this as how I see my role. I'll say that one aspect of my role I see very much as that of acting as a mirror. And isn't it interesting that the Prophet salalahu alayhi wa salam said words to the effect that the believer is a mirror to his brother. So again, it's a highly Islamic activity to do and the hope is that through our knowledge and experience that we can be in some ways a more accurate mirror than perhaps our clients experience in the reflections from their own parents or their own environments." This metaphor of the mirror appeared in Rothman \& Coyle's (2018) study where the scholar participants referenced the notion of the soul of the person being a mirror that can reflect the light of 
God. The metaphor was used in relation to the potential for a person to "polish their mirror" by doing tazkiyat an nafs and thus reflecting the light of the rūh in their soul, as well as the potential for a person to reflect back to a companion the state of their soul. In describing her role as an Islamic psychotherapist, Rayyan also invoked this mirror metaphor:

"I am doing a lot of being their mirror and kind of just pointing out in a clinical sense what I see of who they are. And it's nothing that I'm adding to them. It's like they're giving it to me but they're unable to see it. And again that goes back to Islamic psychology or Islam in general because the Prophet salalahu alayhi wa salam said 'We're mirrors of one another.' And so it's as if I'm a professional mirror."

In these reflections, it is possible to see that participants were engaged in striking an appropriate balance between the positions of "professional psychotherapist" and "Islamic spiritual guide". This seemed to be related to participants' acknowledgement of a shared sense of reverence for the role of a shaykh within the larger Muslim community, as well as their apprehension about delving into territories of the soul that they may not be equipped to navigate. In relation to the former, Harun said: "Really I mean what I do is under the guise of Hakim [traditional Islamic medicine practitioner] but it saves me because it saves me from these other things that can become charged with these ideas that people carry, like 'shaykh', you know, or Sufi shaykh, or Sufism, or tasawwuf. Half of what I'm doing is tașawwuf or part of tasawwuf. Half of it is healing with traditional models of healing in general and a lot of this just being like I said the comforts of just being a professional human being, you know, just being a good counselor.” Efforts at any either/or demarcation were accompanied by accounts of practice that spoke of a "both/and" relationship, often in a qualified way. Although a shaykh may not be confined to higher levels of spiritual attainment but may be equipped to help people with their development at the lower stages of the soul too, participants believed that this type of shaykh, who has the capability and time to support people in their struggles with mental health, is rarely found. As was noted earlier, participants thought that most people are only ever going to be struggling between the three main stages of the soul, with very few going far into the stage of nafs al-mutma'innah. Hence the Islamic 
psychotherapist has a clear position to fill within the Islamic tradition and in the greater global Muslim community.

\section{- Therapists' own Jihād/Tazkiyat an Nafs}

Given participants' conception of their role as being, as Rayyan put it, "a professional mirror", it was understood by most that it is very important for the therapist to polish their mirror so that they can provide a clear reflection of their clients. As described in our study of the Islamic model of the soul, when a person does the work of polishing their mirror and seeks to remove the dunya-related encrustation from the nafs, this is expressly connected to the notion of tazkiyat an nafs or "purification of the soul". In the present study, participants were unequivocal that, for a person truly to be able to do the work of an Islamic psychotherapist, they need to be engaged in the process of purifying their own soul. For example:

"I do feel that as a Muslim therapist because you're considered a murrabi [mentor], because you're considered that guide somebody might consider you as a shaykh that you're supposed to also continuously work on reforming your own self, right. So if you're having these issues and you're just kind of ignoring them, so if you have to go see a therapist or someone you should, but ideally this process of tazkiyat an nafs for your client is also happening within you. And every client that comes in, you could almost see some level of problem within you that they're having. Part of that healing process is going to be like you also work on yourself while you work with them.” (Firas)

"So I think being able to integrate that and being able to live it myself first and foremost. If I'm not living it, clients see through it and they can tell. I really feel like if they see that you strongly believe in it and truly mean it and you're able to get results that that's really powerful for clients.” (Hind)

What participants emphasized here is very similar to what many schools of secular psychotherapy encourage or require in terms of the therapist being in therapy themselves, as we noted earlier. In the case of Freudian, Jungian and other depth approaches, this personal therapy is seen as a vital aspect of 
training for the therapist role. Echoing Hind's statement about the therapist being a living model of the work on the self, Rahim said, "Jung certainly expressed that when he said for instance, the only qualification for a therapist is knowing themselves, therefore in effect they were an analyst, that the training was irrelevant beyond that." More specifically, towards the end of the data excerpt above, Firas links the client's and the therapist's healing process.

Thus, the role of the Islamic psychotherapist was conceived of as requiring more than just training for the job. Rather it was seen as calling for a personal commitment on the part of the therapist to the development of their own soul. In legitimizing this view, participants invoked the need for authenticity (as seen in the quotation from Hind) but also drew upon the wisdom of their own teachers. For example, referring to a teacher in traditional Islamic healing methods, Harun said, "My teacher used to say, 'This is for you, don't think you're out there helping other people, you know, you're helping yourself." He went on to say, "This principle of working on oneself and seeing what we do in the proper light and staying on the journey for our own transformation in a really full way is an important part of what this is about." This point about the therapist's tazkiyat an nafs being central to Islamic psychotherapy and extending beyond what can be gained from training was further stressed by Shahid. He again referenced the mirror analogy saying, "It's not just to get an understanding of the process or whatever, it's also to get some healing, you see. Again, if we use the mirror analogy, how can we hold up a mirror which is truly reflective if we haven't got somewhere ourselves because then our distortions come into the mirror?"

While being seen as a specific requirement for the therapist in Islamic psychotherapy, this feature was also seen as an instance of a broader principle: how the state of the therapist is crucial for the therapeutic process. Rayyan provided a poignant description of what it is like from her perspective for the therapist to use the state of their own heart as a therapeutic resource for connecting with the client and allowing insights to arise for the client's healing process. She said:

"And you have to really be willing to be vulnerable with yourself. Not sharing who you are but as in allowing your heart to be very open while you're in the session with the person so that you can feel where the person is. And I think that's another thing that's like very essential 
in this, where my feeling of Islamic psychology is that the base is suhba, like companionship. And in companionship you are not just physically with the person and not just emotionally with the person, but your heart is literally like on the table with the person. And when it's like that it's... I've found that when I've been able to open my heart to the person and when the person has been willing to accept that openness, then this criteria, or like figuring this out [gesturing to the Islamic model of the soul] is very easy. Because then it's almost like a veil is lifted between us and these problems are just so clear. So even they'll tell me like, you know, 'I've been sitting here and I say things and I'm so amazed at what I'm figuring out about myself even though you've said nothing.' But that only happens when I'm in a state, where I'm able to be open. But if I'm having a difficult time in life or if there's something in the person that's triggering something in me and I'm self-protecting internally, even though my words are the same, my actions are the same, that interaction doesn't happen. And this [pointing at the model] becomes very difficult.”

It might seem that most of what Rayyan is saying here could also have been said by a secular personcentered therapist. What makes her reflection distinctive, however, is that suhba does not simply mean companionship in the sense of being present to one other. Through their presence with each other, the therapist and the client are not just reflecting each other's humanness to the other but are allowing a door to be opened to God's presence where answers and healing can be accessed. When Rayyan says "a veil is lifted between us and these problems are just so clear", what she is saying is that the suhba has created a sacred space where God comes into the session and illuminates the heart of the client, providing openings that would not be possible based on the intentions, knowledge or understanding of the therapist or client on their own. It is as if the therapeutic dyad becomes a triad or, from an Islamic perspective, the perceived duality in the client/therapist dynamic becomes transcended and they are able to witness the One. 


\section{The clinical scope of Islamic psychotherapy: A theoretical model}

The model presented in Figure 1 illustrates the clinical scope of Islamic psychotherapy based on the input of participants in this study. In the center of the Figure are the three main stages of the Islamic model of the soul that we described in Rothman \& Coyle (2018) (nafs al-ammärah bil su, nafs allawwämah, and nafs al-mutma'innah). The fourth box at the top represents the additional stages of the soul referenced in Islamic sources, mentioned by participants in Rothman \& Coyle (2018) and with specific significance in Rothman \& Coyle (2020). This fourth box lists the two additional stages of the soul that were referred to in the present study by Enas: nafs al-radiyyah ("soul well pleased") and nafs al-mardiyyah ("soul well pleasing"). The circle encompassing all of the lower two stages of the soul and a bottom portion of the third stage indicates the parameters of the terrain of operation that participants ascribed to practitioners of Islamic psychotherapy.

\section{[Insert Figure 1 about here]}

Within that terrain, the goal of therapy is to assist the client in moving through the stages of the soul in a non-linear fashion with a focus on progression upward in the model towards the higher stages of the soul. This psychotherapeutic work is mostly confined to the lower two stages of the soul, with movement between nafs al-ammārah bil su and nafs al-lawwämah in a back-and-forth fashion as clients struggle against their nafs, using their 'aql (reason or perception) to turn or orient the qalb (the 'heart' or spiritual center of the person) and remove blockages to their fitrah self. This process is referred to as jihäd an nafs, which encompasses all struggling against the soul at any point from the lower to the highest stages of the soul. Within the jihād an nafs, tahdhīb al-akhlāq is a process in which the therapist engages the client only when they have progressed out of the stage of nafs alammārah and have entered into nafs al-lawwämah, which allows for self-accountability. Here therapists use the muhlikat and munjiyat ("vices" and "virtues") both as indicators of pathology and as devices of treatment to target the balance of relevant character traits in the client according to their treatment needs. The primary objective of treatment in this model is for the client to reach equilibrium in their soul, which is defined as the removal of psychological dysfunction, ranging from narcissism 
to discontent (as depicted in the lower right-hand side of Figure 1), that causes the client to become stuck in one of the lower two stages of the soul and thus to become stationed between lawwamah and muțma innah.

Also, within the stage of nafs al-lawwämah and higher, and as a part of the therapeutic application of jihäd an nafs, the client is encouraged to engage in tazkiyat an nafs through the therapist's directive use of Islamic practices such as murāqabah (meditation) and tafakkur (contemplation). Once a client has progressed further into the stage of nafs al-lawwämah, the therapist can use techniques such as guided imagery to direct the client toward experiencing moments of the stage of nafs al-mutma 'innah as a motivating factor to progress further along the upward trajectory of the soul, ranging from well-being to gnosis or spiritual knowledge (as depicted in the upper right-hand side of Figure 1). At the point where a client reaches into the stage of nafs al-mutma 'innah and is capable of progressing further into that stage, they move beyond the scope of Islamic psychotherapy and into the terrain of the shaykh of tașawwuf. The shaykh can continue working with the client to progress further into the higher stages of the soul, albeit rarely, potentially beyond nafs almutma'innah to nafs al radiyyah, nafs al mardiyyah, and to even higher stages. This is represented by the upper circle in the center of the Figure which encompasses an upper portion of nafs al-lawwāmah and all of the higher stages of the soul.

\section{Discussion}

Determining where the line should be drawn between Islamic spiritual guidance and psychological guidance from an Islamic model is not an easy process and is accompanied by a host of qualifiers and caveats. Almost all the participants interviewed in this study seemed to believe that a blurred line should be permitted and may be necessary because if Islamic psychotherapy were to avoid the spiritual, it would simply become psychotherapy with Muslims. The role of the Islamic psychotherapist operating within an Islamic paradigm differs from that of a secular psychotherapist in that the inner world that they are inviting the client to explore is not limited to mental processes and cognition but involves a holistic picture of the human being and entails the exploration of the soul. 
Nonetheless, caution is required, particularly when it comes to engaging and understanding the rūh as the deeper connection with the reality of the soul in relation to God.

Here it may be useful to invoke concepts and categories that participants appeared to draw upon and that are found in Abu Hamid al-Ghazali's $11^{\text {th }}$ century text Ihya ' 'Ulüm al-Dinn (The Revival of the Religious Sciences). There al-Ghazali (2014) discussed the process of achieving psychospiritual health or well-being and invoked the need to develop self-awareness or inkishaaf. In the Islamic tradition, this denotes a process whereby, through obtaining awareness of one's deficiencies, one can access the material needed for working on such traits to bring them into balance to achieve equilibrium and thus well-being (Keshavarzi and Khan, 2018).

Al-Ghazali (2014) proposed that there are two ways of acquiring such self-awareness: adopting a shaykh or taking "a sound companion" who can help facilitate this introspective selfdiscovery. Placing oneself in the hands of a shaykh involves a disciplined commitment to study and development under guidance. This is directed towards an advanced process of self-awareness that orients to a deep inner knowledge of the self or soul of the person, with the goal of striving toward higher stages of the soul (Al-Shabrawi, 2009). However, this path may not be practicable for many who are struggling with more foundational aspects of day-to-day life tribulations and imbalances. The alternative is not to try to "go it alone": many scholars have stressed that supervision is needed on the path of spiritual development (Ar-Razi, 2007; Badri, 2013; Hermansen, 1988; Keshavarzi and Haque, 2013). Al-Ghazali (2014: 257) suggested that, in this case, one should "seek a sound companion, knowledgeable in the secrets of this matter, and appoint him as an observer of his self, to note his states and alert him to his faults." This person should have some knowledge of the landscape of the inner life of the human being and the process of self and spiritual development. Al-Ghazali's view was that, while this "sound companion" may not be at the level of a shaykh, having a companion who has perhaps trodden the path of spiritual development with some effort and success is the next best thing. What al-Ghazali has articulated here opens the doorway to conceptualizing the role of the 
therapist within the Islamic tradition in terms that are Islamically recognizable but are distinct from the role of the shaykh of tașawwuf (Khan, Keshavarzi and Rothman, 2020).

In order to act as a "sound companion" though, the spiritual state of the therapist becomes relevant: the therapist needs to acquire the Islamic knowledge of the soul not only in theory but as experiential knowledge. As we noted earlier, it is recognized in many schools of secular therapy that the competent therapist must be engaged in working on and fostering ongoing growth in themselves. Indeed, it has been said that a therapist can only get their client to a stage of growth that the therapist has achieved him or herself. Similarly, it could be suggested that the Islamic psychotherapist should have personal experience in and an active commitment to working toward their advancement through the stages of the soul in the process of jihād an nafs.

The second main contribution that this research makes towards conceptualizing the clinical scope of Islamic psychotherapy is to locate the majority of the therapeutic focus between the stages of nafs al-ammārah bil su and nafs al-lawwāmah. In addition, the experience-based model in Figure 1 posits that the stage of nafs al-lawwämah is where the Islamic psychotherapist concentrates his or her clinical approach, with the aim of moving the client further into this stage because it is here that the goal of psycho-spiritual equilibrium can be reached. Although others have specified that the goal of the Islamic psychotherapist is to help a client attain equilibrium/i'tidaal (see Keshavarzi and Khan, 2018), it has never been previously made clear how or where this happens in relation to the Islamic model of the soul.

Another aspect of the stages of the soul that has been alluded to in the literature but has not been significantly dealt with or understood is how to engage the stage of nafs al-mutma'innah. As noted by Keshavarzi and Khan (2018), Khan, Keshavarzi and Rothman (2020), and others, this stage is generally thought of as lying outside the scope of psychotherapy or even out of reach for most people in general. While that notion was validated by many participants in this study, others found it useful to invoke this stage and described a way of doing so, if only in particular instances. In those instances, the introduction of traditional Islamic practices of murāqabah (meditation) and tafakkur 
(contemplation) was believed capable of helping clients to cultivate some familiarity with this higher stage of the soul which is defined and experienced as "the soul at rest". This provides an example of how it was believed that the soul could be prepared for inter-stage progression.

The stages of the soul also help identify the point at which an Islamic psychotherapist who is acting as a "sound companion" for a client needs to refer them to a shaykh of tașawwuf. The findings from this study identify this (represented by the dotted line in Figure 1) as lying at the very beginning of the stage of mutma'innah when the person has reached a point of development that allows for more sustained experiences of being stationed in this higher stage of the nafs. Keshavarzi and Khan (2018) state that the eventual goal is to reach what they call ittihaad (integrative unity), and which they attribute to the stage of mutma 'innah. They see the realization of that goal as lying beyond the scope of the Islamic psychotherapist and is best facilitated by referral to a shaykh. This contention is corroborated by the present study which further specifies that a client is better suited to working with a shaykh when they have established themselves more firmly on the other side of the line of equilibrium.

While equilibrium is posited as the general point where the domain of Islamic psychotherapy ends and that of the shaykh takes over, this study did not include shayukh (plural of shaykh) of tașawwuf among its participants. This was due to its specific focus on Islamic psychotherapy and its practice. In retrospect, theoretical sampling might usefully have continued beyond the point at which we believed we had reached saturation. As it stands, the study might have generated an overly-sharp distinction between the roles of the shaykh and the Islamic psychotherapist, even if, as we noted earlier, participants' demarcations were accompanied by accounts of practice that spoke of a qualified "both/and" relationship between the roles. It may be that what has been conceptualized as lying within the scope of a shaykh also could include (some of) what has been described as the role of the Islamic psychotherapist. Conversely, facilitating and guiding movement beyond the stage of nafs almuța innah could lie within the scope of an Islamic psychotherapist. This may depend on the practitioner in each case and their individual capacity in regard to the domains. It is plausible that a shaykh could be equipped to engage with the work of helping a person deal with struggling through 
the lower two stages, although participants believed that this type of shaykh is not commonly encountered, either due to a lack of understanding of mental health and/or lack of the time required to assist people through these struggles. From a mental health perspective, such a shaykh needs to have some understanding of aspects of psychotherapy or at least counseling skills. It is also possible that an Islamic psychotherapist could have or acquire the traditional and experiential knowledge required to guide people further in the trajectory of the soul's development, into what has been identified as lying within the scope of the shaykh.

In conclusion, this paper has extended the model of Islamic psychotherapy presented in Rothman \& Coyle (2020) by examining the clinical scope of Islamic psychotherapy in a datagrounded way, drawing upon the experiences of Muslim psychotherapists who believed that they integrate Islamic conceptions of psychology into their clinical practice. In specific terms, that model has been extended principally in relation to the stages of the soul with which Islamic psychotherapy is concerned and the potential for inter-stage movement, and the relationships between and demarcation of the roles of the Islamic psychotherapist and the shaykh of tasawwuf. In this respect, the paper exemplifies an important stage in any ongoing grounded theory process and has also identified how a consideration of the clinical scope of Islamic psychotherapy might be further extended by including the perspectives and experiences of shayukh. Research interviews with shayukh could usefully aim to elucidate traditional spiritual healing approaches; understand what aspects of tazkiyat an nafs could be used within a therapeutic encounter to facilitate client movement toward equilibrium; and gain insight into traditional spiritual practices such as murāqabah and tafakkur and the mechanisms of change associated with them. It would also be useful to explore what types of dialogue might prove fruitful between Islamic psychotherapists and shayukh to help delineate their roles and create avenues for support and cooperation. 


\section{Compliance with ethical standards}

Ethical approval All procedures performed in studies involving human participants were in accordance with the ethical standards of the institutional research committee and with the 1964 Helsinki declaration and its later amendments or comparable ethical standards.

Informed consent Informed consent was obtained from all individual participants in the study.

\section{References}

Abdullab, S. (2007). Islam and counseling: Models of practice in Muslim communal life. Journal of Pastoral Counseling, 42, 42-55.

Abdullah, C. H. B., Abidin, Z. B. Z., Hissan, W. S. M., Kechil, R., Razali, W. N., \& Zin, M. Z. M. (2013). The effectiveness of generalized anxiety disorder intervention through Islamic psychotherapy: The preliminary study. Asian Social Science, 9(13), 157-162. https://doi.org/10.5539/ass.v9n13p157

Al Ghazali, A. H. (2014). Mukhtasar ihya ulum ad-din (M. Khalaf, trans.) (2 $2^{\text {nd }}$ ed.). Lypia/Nikosia, Cyprus: Spohr Publishers.

Ali, O. M., Milstein, G., \& Marzuk, P. M. (2005). The Imam's role in meeting the counseling needs of Muslim communities in the United States. Psychiatric Services, 56(2), 202-205.

Al-Karam, C. Y. (Ed.). (2018). Islamically integrated psychotherapy: Uniting faith and professional practice. West Conshohocken, PA: Templeton Press.

Al-Razi, A. B. M. ibn Z. (2007). Razi’s traditional psychology (A. J. Arberry, Trans.). Damascus: Kazi Publications, Inc.

Al-Shabrawi, S. A. (2009). Degrees of the soul: Spiritual stations on the Sufi path (M. Al-Badawi, Trans.). Cambridge: The Quilliam Press. 
Badri, M. (2013). Abu Zayd al-Balkhi's 'Sustenance of the soul': The cognitive behavior therapy of a ninth century physician. London: The International Institute of Islamic Thought.

Charmaz, K. (2014). Constructing grounded theory ( $2^{\text {nd }}$ ed.). Thousand Oaks, CA: SAGE.

Evans, G. R. (Ed.) (2000). A history of pastoral care. London: Cassell.

Glaser, B., \& Strauss, A. (1967). The discovery of grounded theory: Strategies for qualitative research. New York: Aldine.

Hathaway, W. L. (2009). Clinical use of explicit religious approaches: Christian role integration issues. Theophostic Prayer Ministry, 28(2), 105-112.

Hermansen, M. K. (1988). Shāh Walī Allāh's theory of the subtle spiritual centers (Lațā'if): A Sufi model of personhood and self-transformation. Journal of Near Eastern Studies, 47(1), 1-25. https://doi.org/10.1086/jnes.47.1.3693678

Jurich, J. (1998). A cross-cultural study of 'The Conference of the Birds': The shaikh/disciple and therapist/patient relationship in Sufism and psychotherapy. (Unpublished doctoral dissertation). New York University, New York.

Keshavarzi, H., \& Haque, A. (2013). Outlining a psychotherapy model for enhancing Muslim mental health within an Islamic context. International Journal for the Psychology of Religion, 23(3), 230-249. https://doi.org/10.1080/10508619.2012.712000

Keshavarzi, H., \& Khan, F. (2018). Outlining a case illustration of traditional Islamically integrated psychotherapy. In C. Y. Al-Karam (Ed.), Islamically integrated psychotherapy: Uniting faith and professional practice (pp. 175-207). West Conshohocken, PA: Templeton Press.

Khan, F., Keshavarzi, H., \& Rothman, A. (2020). The role of the TIIP therapist: Scope of practice and proposed competencies. In H. Keshavarzi, F. Khan, B. Ali \& R. Awaad (Eds.), Applying Islamic principles to clinical mental health care: Introducing Traditional Islamically 
Integrated Psychotherapy (pp. 38-65). New York: Routledge.

Naz, S., \& Khalily, M. T. (2016). Indigenous adoption of Novaco's model of anger management among individuals with psychiatric problems in Pakistan. Journal of Religion and Health, 55(2), 439-447. https://doi.org/10.1007/s10943-015-0012-y

Payne, S. (2021). Grounded theory. In E. Lyons \& A. Coyle (Eds.), Analysing qualitative data in psychology ( $3^{\text {rd }}$ ed., pp. 196-222). London: SAGE.

Richards, G. (2010). Putting psychology in its place: Critical historical perspectives (3rd ed.). London: Routledge.

Rothman, A. (2021). Developing a model of Islamic psychology and psychotherapy: Islamic theology and contemporary understandings of psychology. London: Routledge.

Rothman, A. \& Coyle, A. (2018). Toward a framework for Islamic psychology and psychotherapy: An Islamic model of the soul. Journal of Religion and Health. 57(5), 1731-1744.

Rothman, A. \& Coyle, A. (2020). Conceptualizing an Islamic psychotherapy: A grounded theory study. Spirituality in Clinical Practice, 7(3), 197-213.

Strunk, O. (1993). A prolegomenon to a history of pastoral counseling. In R. J. Wicks, R. D. Parsons, \& D. Capps (Eds.), Clinical handbook of pastoral counselling, volume 1 (pp. 14-25). Mahwah, NJ: Paulist Press. 
Table 1. Participants' background information

\begin{tabular}{|c|c|c|c|}
\hline Pseudonym & Location & $\begin{array}{l}\text { Training } \\
\text { (self-descriptions) }\end{array}$ & $\begin{array}{l}\text { Mode of integration } \\
\text { and levels of the soul } \\
\text { engaged in practice }\end{array}$ \\
\hline Fatima & USA & $\begin{array}{l}\text { Cognitive behavioural therapy } \\
\text { (CBT); relational }\end{array}$ & \multirow{6}{*}{$\begin{array}{l}\text { Ad hoc integration of } \\
\text { Islamic principles into } \\
\text { Western secular } \\
\text { therapeutic approaches }\end{array}$} \\
\hline Maha & USA & $\begin{array}{l}\text { CBT; mindfulness; person- } \\
\text { centered }\end{array}$ & \\
\hline Matthew & USA & Existential; humanistic; somatic & \\
\hline Obaid & Qatar & $\begin{array}{l}\text { Clinical psychology; } \\
\text { neuropsychology }\end{array}$ & \\
\hline Safa & USA & Eclectic & \\
\hline Siraj & United Kingdom & CBT & \\
\hline Firas & $\overline{\text { USA }}$ & Clinical psychology; CBT & \multirow{8}{*}{$\begin{array}{l}\text { Deliberate, concerted } \\
\text { integration of the } \\
\text { Islamic model of the } \\
\text { soul to inform an } \\
\text { Islamic therapeutic } \\
\text { approach } \\
\text { Levels of the soul } \\
\text { engaged: } \\
\text { Nafs, Aql, Qalb }\end{array}$} \\
\hline Hind & USA & CBT; person-centered & \\
\hline Hamit & USA & Emotional freedom techniques & \\
\hline Kabir & USA & CBT; existential; humanistic & \\
\hline Mahmoud & United Kingdom & CBT; psychodynamic & \\
\hline Rayyan & Turkey & Humanistic & \\
\hline Samir & United Kingdom & Eclectic & \\
\hline Shahid & United Kingdom & Psychoanalytic & \\
\hline Enas & Saudi Arabia & Eclectic & \multirow{4}{*}{$\begin{array}{l}\text { Active engagement of } \\
\text { all levels of the soul } \\
\text { guided by traditional } \\
\text { Islamic spiritual } \\
\text { healing practices } \\
\text { Levels of the soul } \\
\text { engaged: } \\
\text { Nafs, Aql, Qalb, Ruh }\end{array}$} \\
\hline Harun & USA & Somatic & \\
\hline Mustafa & Sudan & Clinical psychology & \\
\hline Rahim & United Kingdom & Psychodynamic & \\
\hline
\end{tabular}


Table 2. The application of two theoretical categories of the Islamic model of the soul to an Islamic psychotherapy (seen in the sub-categories)

\begin{tabular}{|c|c|}
\hline Main categories & Sub-categories \\
\hline Stages of the soul & $\begin{array}{l}\text { Majority of psychotherapy is between Nafs al Amara bil su } \\
\text { and Nafs al Lawwamahh } \\
\text { Movement through the stages as treatment goal } \\
\text { Nafs al Mutmainah and beyond }\end{array}$ \\
\hline Development of the soul & $\begin{array}{l}\text { Development of the soul of the client: Treatment approach } \\
\text { - Jihad an Nafs (struggle of the soul) } \\
\text { - Tahdhib al Akhlaq (reformation of character) } \\
\text { Development of the soul of the therapist: Training approach } \\
\text { - Defining and demarcating the role of the Islamic therapist } \\
\text { - Therapist's own Jihad/Tazkiyat an Nafs }\end{array}$ \\
\hline
\end{tabular}




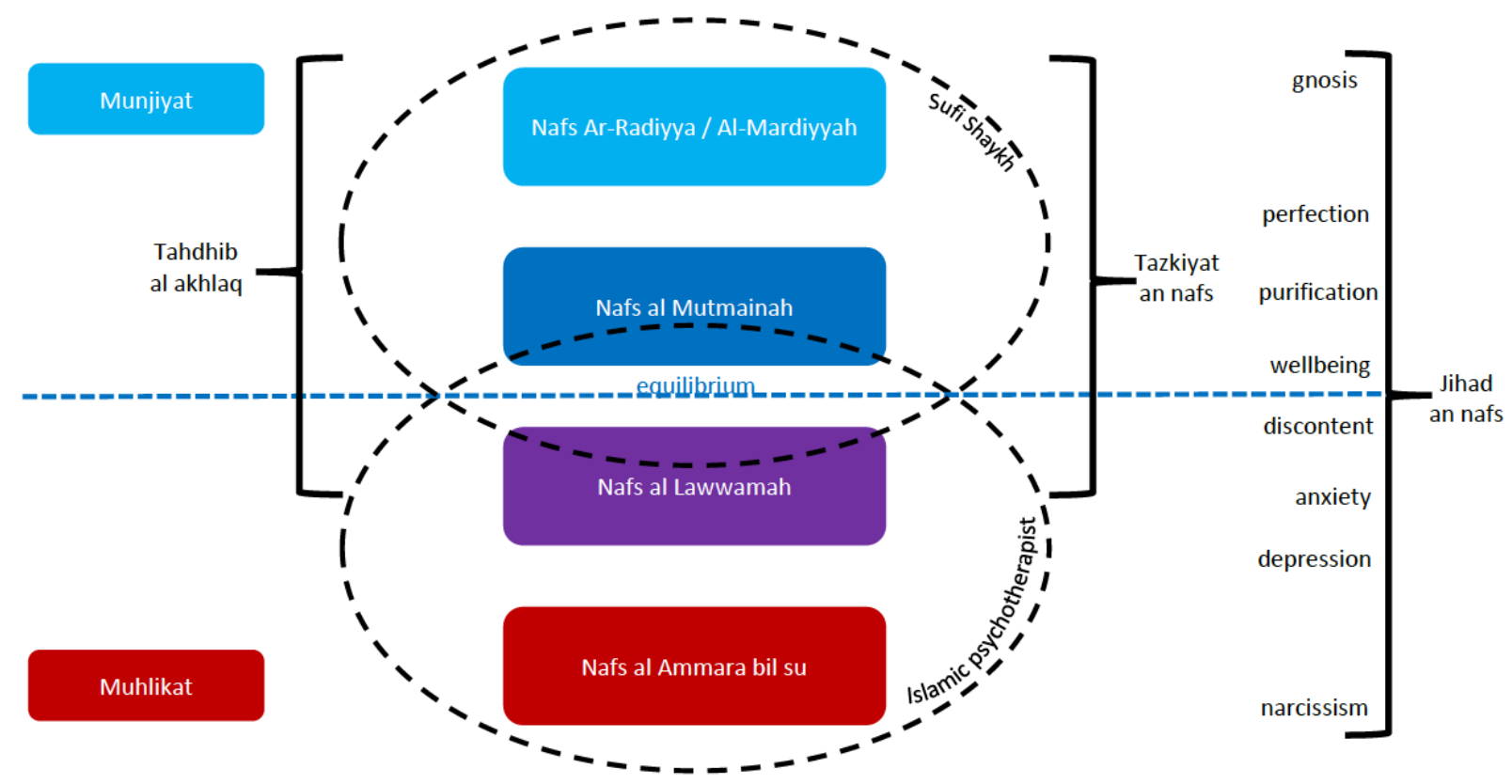

Figure 1. A model of the clinical scope of Islamic psychotherapy 